ORIGINAL ARTICLE

Saliha Baykal ${ }^{1}$

Ayşin Nalbantoglu²

${ }^{1}$ Namık Kemal University, Medical Faculty,Department of Child and Adolescent Mental Health and Diseases, Tekirdağ, Turkey

${ }^{2}$ Namık Kemal University, Medical Faculty, Department of Pediatrics, Tekirdağ, Turkey

Corresponding Author: Saliha Baykal

Namık Kemal University, Medical Faculty, Department of Child and Adolescent Mental Health and Diseases, Tekirdăg, Turkey

Tel: +90 5054844386

E-mail: salihabaykal35@hotmail.com

Received: 22.02.2019

Acceptance: 14.06.2019

DOI: $10.18521 / \mathrm{ktd} .530900$

Konuralp Medical Journal e-ISSN1309-3878

konuralptipdergi@duzce.edu.tr konuralptipdergisi@gmail.com www.konuralptipdergi.duzce.edu.tr

\section{An Examination of Emotion Regulation and Associated Factors in Attention Deficit-Hyperactivity Disorder ABSTRACT}

Objective: Emotion regulation difficulties (ERD) such as anger, irritability and frustration intolerance leading to severe functional losses may be observed in attention deficithyperactivity disorder (ADHD). The purpose of this study was to compare children and adults diagnosed with ADHD and a healthy control group in terms of emotion regulation characteristics and to examine factors potentially associated with ERD.

Methods: The study was performed with 72 children/adults aged 6-18 diagnosed with ADHD based on DSM-V diagnostic criteria at the Namık Kemal University Medical School of Child and Adolescent Psychiatry Polyclinic, Turkey, and 30 healthy controls. The Schedule for Affective Disorders and Schizophrenia for School-Age Children - Present and Lifetime Version (K-SADS-PL), a semi-structured interview form, was used to determine comorbidities. ERD scores (ERD=attention+anxiety/depression+aggression subscales) were determined using the Childhood Behavior Checklist (CBCL).

Results: Mean ERD scores were $189.45 \pm 19.33$ in the ADHD group and $164.13 \pm 9.94$ in the healthy control group. A significant difference was determined in ERD scores between the two groups $\left(\mathrm{p}<0.001^{* *}\right)$. When the ADHD group was evaluated in terms of clinical characteristics, comorbid psychiatric disorders were not associated with ERD, but combined type ADHD characteristics emerged as significant predictors for $\operatorname{ERD}\left(\mathrm{p}=0.011^{*}\right)$.

Conclusions: The results of this research revealed significantly greater ERD in individuals diagnosed with ADHD compared to healthy controls, and that combined type ADHD is a predictor for ERD. Since ERD accompanying ADHD lead to greater function loss in the individual and are associated with persistence of the disorder in adulthood, these are important clinical characteristics also requiring evaluation during the diagnosis and treatment of ADHD.

Keywords: ADHD, Emotion Regulation, Comorbidity

\section{Dikkat Eksikliği Hiperaktivite Bozukluğunda Duygu Düzenleme ve İlişkili Faktörlerin İncelenmesi ÖZET}

Amaç: Dikkat Eksikliği Hiperaktivite Bozukluğu'nda (DEHB) önemli fonksiyonel kayıplara neden olan öfke, irritabilite ve engellenme toleranssızlığı gibi duygu düzenleme güçlükleri (DDG) görülebilir. Bu araştırmada DEHB tanılı çocuk ve ergenler ile sağlıklı kontrol grubunu duygu düzenleme özellikleri bakımından karşılaştırmak, duygu düzenleme güçlüğü ile ilişkili olabilecek faktörleri incelemek amaçlanmıştır.

Gereç ve Yöntem: Araştırma Namık Kemal Üniversitesi Tıp Fakültesi, Çocuk ve Ergen Psikiyatri polikliniğinde DSM-V tanı kriterlerine göre DEHB tanısı konulan 6-18 yaş aralığında 72 çocuk-ergen ve 30 sağlıklı kontrol ile yürütülmüştür. Okul Çağı Çocukları için Duygulanım Bozuklukları ve Şizofreni Görüşme Çizelgesi - Şimdi ve Yaşam Boyu Şekli (ÇDŞG - ŞY) yarı yapılandırılmış görüşme formu kullanılarak komorbiditeler belirlenmiştir. Çocukluk Çağı Davranış Değerlendirme Ölçeği (ÇDDÖ) ile duygu düzenleme güçlüğü (DDG=dikkat+anksiyete/depresyon+agresyon alt ölçekleri) puanı elde edilmiştir.

Bulgular: DEHB grubunda DDG puanı 1--89.45 19.33 iken, sağlıklı kontrol grubunda DDG puanı $164.13 \pm 9.94$ olarak bulunmuștur. İki grup arasında DDG puanları bakımından anlamlı fark saptanmıştır $\left(\mathrm{p}<0.001^{* *}\right)$. DEHB grubu klinik özellikler bakımından değerlendirildiğinde eş psikiyatrik bozuklukların DDG ile ilişkili olmadığı, DEHB bileşik görünüm özelliklerinin ise DDG için önemli yordayıcı olduğu sonucu elde edilmiştir $(\mathrm{p}=0.011 *)$.

Sonuç: Bu araştırmanın sonuçları DEHB tanılı bireylerde DDG'nün sağlıklı kontrollere göre anlamlı düzeyde fazla olduğu ve DEHB bileşik görünümün DDG için yordayıcı olduğu sonucunu ortaya koymuştur. DEHB'ye eşlik eden duygu düzenleme güçlügü, kişide daha fazla işlevsellik kaybına yol aç̧tğı ve bozukluğun yetişkin yaşta devamı ile ilişkilendirildiğinden, DEHB tanı ve tedavi sürecinde ayrıca ele alınması gereken önemli klinik özelliklerdendir.

Anahtar Kelimeler: DEHB, Duygu Düzenleme, Komorbidite 


\section{INTRODUCTION}

Emotion regulation involves intrinsic and extrinsic processes responsible for managing, evaluating and monitoring emotional reactions, and particularly features such as intensity of emotion, its temporal characteristics and goal-orientation (1). Emotion regulation difficulty (ERD) plays a role in the development of several psychopathologies and is one of the fundamental factors needing to be considered in their treatment. A significant proportion of the psychopathology categories defined in DSM-5 are characterized by ERD. ERD represents the basis of depressive disorder, bipolar disorder and anxiety disorders, and is also frequently seen in conditions such as attention deficit-hyperactivity disorder (ADHD), borderline personality disorder and post-traumatic stress disorder.

In addition to fundamental symptoms as inattention, hyperactivity and impulsivity in ADHD, ERDs such as anger, irritability and low frustration tolerance are also common. Research involving hospital populations has determined ERDs in 24-50\% of children diagnosed with ADHD (2). One community-based study reported ERD in $38 \%$ of children diagnosed with ADHD, and stated that this rate was 10 times higher than in the normal community (3). This prevalence has led to a debate about the nature of emotional symptoms in individuals with ADHD and whether these should be included in diagnostic terminology. One of the main obstacles to the inclusion of ERD in the diagnostic terminology as a feature of ADHD is inter-patient clinical differences $(3,4)$.

While there is no consensus regarding the scales used in assessing ERD, one meta-analysis revealed consistent elevation in the Childhood Behavior Checklist (CBCL) attention, anxiety/depression and aggression subscales in children diagnosed with bipolar disorder (5). Based on these data, the CBCL anxiety/depression, attention problems and aggressive behavior subscales were defined as the CBCL-Pediatric Bipolar Disorder profile (6). Evaluation in terms of bipolar disorder is recommended in cases with CBCL-Pediatric Bipolar Disorder profile values above ( $\geq 2$ SD), while values of $180-210$ ( $\geq 1$ SD, $\leq$ 2 SD) have been associated with ERD seen in cases of ADHD (7).

The purpose of this study was to compare children and adults diagnosed with ADHD and a healthy control group in terms of emotion regulation characteristics and to examine factors potentially associated with ERD in a group diagnosed with ADHD.

\section{MATERIAL AND METHODS}

Establishment of the Sample Group: This research was conducted at the Namık Kemal University Medical School Department of Child and Adolescent Psychiatry Polyclinic, Turkey. Seventy-two children and adults aged 6-18 years, diagnosed with ADHD on the basis of DSM-5 diagnostic criteria and not using drug therapy for at least the precious six months were included in the study. Comorbidities in children and adolescents were determined using the Schedule for Affective Disorders and Schizophrenia for School-Age Children - Present and Lifetime Version (K-SADSPL) semi-structured interview form. Subjects with additional diagnoses of anxiety disorder, bipolar disorder, intellectual disability or autism were excluded. A control was established consisting of 30 healthy children and adolescents aged $6-18$ years presenting to the Pediatric Health and Diseases healthy child polyclinic and with no chronic disease. The control group was evaluated by a child and adolescent psychiatry specialist, and subjects with previous or present psychiatric disease were excluded from the research.

A sociodemographic data form prepared by the authors was completed for the ADHD and control groups in the light of information obtained from participants agreeing to take part and from their parents. In addition, mean parental scores regarding problem areas were obtained with the CBCL (4-18 years).

Approval for this study was granted by the Namık Kemal University Non-Invasive Clinic Research Ethical Committee (date and protocol number 2018.154.11.04).

Schedule for Affective Disorders and Schizophrenia for School-Age Children Present and Lifetime Version (K-SADS-PL): This semi-structured interview form was developed by Kaufman et al. in 1997 for the purpose of determining past and present psychopathologies in children and adolescents based on DSM-III-R and DSM-IV diagnostic criteria (8). The validity and reliability of the Turkish version were established by Gökler et al. in 2004 (9). The form consists of three parts, a structured initial interview, a screening interview for diagnostic purposes, and a general evaluation scale for children. K-SADS-PL evaluates the severity of symptoms in the form of 'none,' 'below threshold,' and 'threshold' and provides information concerning the presence of symptoms in diagnosed subjects.

Childhood Behavior Checklist (CBCL): The scale evaluates behavioral problems in children and young people in the 4-18 age group in the light of information received from parents or caregivers. It was developed by Achenbach et al (10). The scale consists of 118 items. Problem behaviors are rated 0,1 or 2 , according to frequency of occurrence in the previous six months, and the items are grouped under various subscales. Two separate behavioral symptom scores are obtained from the scale, 'internalizing' and 'externalizing.' The internalizing group consists of anxiety/depression, social introversion and somatic symptoms test totals, and the externalizing group of 
noncompliance with rules and aggressive behaviors test totals. In addition, the scale also contains 'social problems, thought problems and attention problems' subtests that are not included in either group. A 'total problem score' is obtained from the entire scale. The scale also contains a competency section that assesses the child's activities, sociability and academic performance. The reliability and validity of the Turkish-language version were studied by Erol et al. in 1995.

Statistical Analysis: Numerical data were expressed as mean \pm standard deviation, and categorical variables as number and percentage (\%). The Kolmogorov-Smirnov test was applied to test the normality of distribution of continuous variables. Student's test and the chi-square test were used for group comparisons, depending on statistical assumptions. Multiple regression analysis was used to determine independent variables with a potential effect on ERD-dependent variables. p values $<0.05$ were regarded as statistically significant. Data analysis was performed on SPSS 17.0 for Windows (SPSS Inc., Chicago, USA) software.

\section{RESULTS}

The study was conducted with 72 children and adolescents diagnosed with ADHD and 30 healthy controls. Mean ages were $8.76 \pm 2.09$ years in the ADHD group and $9.46 \pm 1.54$ in the control group. The difference in ages between the two groups was not statistically significant $(\mathrm{p}=0.06)$. Girls constituted $16.7 \%(n=12)$ of the ADHD group and boys $83.3 \%(n=60)$, while the control group consisted of $46.7 \%(n=14)$ girls and $53.3 \%(n=16)$ boys. The gender difference between the two groups was statistically significant ( $\mathrm{p}=0.006)$.

When the ADHD group was evaluated in terms of psychiatric comorbidities, oppositional defiant disorder (ODD) was present in $18.1 \%$ $(n=13)$, behavioral disorder (BD) in $2.8 \%(n=2)$, elimination disorder in $13.9 \quad(\mathrm{n}=10)$, obsessive compulsive disorder (OCD) in $1.4 \%(\mathrm{n}=1)$, tic disorder in $16.7 \%(\mathrm{n}=12)$, and specific learning disability in $9.7 \%(n=7)$. Comparison of the ADHD and control groups in terms of CBCL subscale scores and ERD scores revealed significantly higher CBCL introversion/depression, social problems, noncompliance with rules and aggressive behavior subscale scores and ERD scores in the ADHD group than in the control group (Table 1).

At evaluation of the ADHD group in terms of clinical characteristics and ERD scores, the ERD score in subjects with combined type ADHD was $194.64 \pm 18.04$, compared to $176.85 \pm 16.63$ in those with primarily inattentive $\mathrm{ADHD}$, and the difference between the two was statistically significant $\left(p<0.001^{* *}\right)$. Mean ERD score in the group with accompanying diagnosis of ODD was $198.30 \pm 14.95$, compared to $187.50 \pm 19.74$ in those with no comorbid ODD. The difference was not statistically significant $(p=0.06)$. No relation was determined between other psychiatric comorbidities, age or gender variables and ERD scores.

Table 1. Comparison of Childhood Behavioral Rating Scale Subscale Scores between the Attention DeficitHyperactivity group and the Healthy Control Group

\begin{tabular}{lcccc}
\hline & $\begin{array}{c}\text { ADHD Group } \\
(\text { Mean } \pm \text { SD) }\end{array}$ & $\begin{array}{c}\text { Control Group } \\
(\text { Mean } \pm \text { SD) }\end{array}$ & F & P \\
\hline Anxiety/Depression & $60.25 \pm 7.69$ & $58.80 \pm 6.46$ & 2.22 & 0.36 \\
\hline Introversion/Depression & $59.50 \pm 8.16$ & $55.66 \pm 5.08$ & 5.69 & $0.01^{*}$ \\
\hline Somatic Symptoms & $55.61 \pm 7.38$ & $56.86 \pm 7.39$ & 0.38 & 0.43 \\
\hline Social Problems & $61.43 \pm 8.13$ & $55.03 \pm 5.49$ & 3.46 & $<0.001^{*}$ \\
\hline Thought Problems & $58.73 \pm 7.70$ & $55.50 \pm 6.36$ & 3.32 & $0.04^{*}$ \\
\hline Attention & $65.66 \pm 7.14$ & $51.60 \pm 1.83$ & 22.75 & $<0.001^{* *}$ \\
\hline Noncompliance with Rules & $58.33 \pm 7.18$ & $51.36 \pm 1.97$ & 49.81 & $<0.001^{* *}$ \\
\hline Aggressive Behavior & $63.56 \pm 9.26$ & $53.76 \pm 4.32$ & 16.56 & $<0.001^{* *}$ \\
\hline ERD Score(Anxiety/Depression+Attention+ & $189.45 \pm 19.33$ & $164.13 \pm 9.94$ & 21.26 & $<0.001^{* *}$ \\
Aggressive Behavior) & & & & \\
\hline ADHD: Attention Deficit-Hyperactivity Disorder, ERD: Emotional Regulation Difficulty, SD: Standard Deviation, *p<0.05
\end{tabular}

Multiple regression analysis was performed since accompanying diagnosis of ODD was more common in subjects with combined type ADHD. A regression model was established taking ERD scores as the dependent variable, and age, parental ages, parental education levels, family socioeconomic level and potentially associated additional psychiatric diagnoses as independent variables. The forward stepwise method was used in this model to determine whether independent variables predicted ERD scores in ADHD. Only combined type ADHD was determined was observed to predict ERD scores (Table 2). The other dependent variables of ODD comorbidity $(p=0.99)$, age $(p=0.85)$, age of mother $(p=0.59)$, age of father $(\mathrm{p}=0.24)$, mother's education level $(\mathrm{p}=0.15)$, father's education level $(\mathrm{p}=0.28)$, and family socioeconomic level $(\mathrm{p}=0.20)$ were not identified as predictors of ERD scores. 
Table 2. Multiple Regression Analysis Results for Predictive Independent Variables for ERD in the ADHD Group

\begin{tabular}{lccc}
\hline & $\begin{array}{c}\text { Regression } \\
\text { Coefficient (b) }\end{array}$ & $\begin{array}{c}\text { Standardized Regression } \\
\text { Coefficient (B) }\end{array}$ & $\mathrm{p}$ \\
\hline Constant & 159.55 & 12.43 & 0.000 \\
\hline ADHD clinical type & 8.88 & 0.40 & 2.67 \\
\hline $\begin{array}{l}\text { ADHD: Attention Deficit-Hyperactivity Disorder, ERD: Emotional Regulation Difficulty, ODD: Oppositional Defiant Disorder, F=7.16, } \\
\mathrm{df}=1, \mathrm{r}=0.403, \mathrm{r} 2=0.162\end{array}$
\end{tabular}

\section{DISCUSSION}

Our study compared emotional control characteristics in children and adolescents with ADHD with those of healthy controls. Our findings revealed significantly greater ERD in individuals diagnosed with ADHD compared to the healthy control group, and that combined type ADHD is a predictor for ERD.

ADHD has been defined as a neurodevelopmental disorder characterized by inattention, hyperactivity and impulsivity incompatible with age and leading to impairment in at least two areas of life (11). Studies to date have emphasized the presence of anger, irritability and low tolerance of stress in a significant proportion of children diagnosed with ADHD, and have considered these symptoms collectively as emotional symptoms. However, since emotional symptoms are not specific to ADHD they have not been considered among the basic components of ADHD. Several studies have shown that the presence of ERD accompanying ADHD is associated with greater social impairment and increased use of therapeutic services $(12,13,14)$. Therefore, although ERD is not regarded as one of the basic features of ADHD, it is still important to determine whether or not it accompanies the disorder. One study of adolescents diagnosed with ADHD reported higher emotional reactivity levels compared to a control group $(12,15)$. Another study compared the emotional regulation skills of children diagnosed with ADHD and their mothers with those of a control group, and determined that both children with ADHD and their mothers experienced greater ERD compared to a control group (16). In agreement with that study, our findings also show greater ERD in children and adolescents diagnosed with ADHD compared to the healthy control group.

Impairment has been shown in selfregulation functions that establish behavior control through effective regulation of impulsivity and emotional experiences in the formation of emotion in individuals diagnosed with ADHD. Barkley defined these two concepts as "emotional instability" and "deficient emotional selfregulation" and reported that these may both be impaired in different forms in different types of ADHD (17). Studies examining ERD in different clinical forms of ADHD have emphasized that ERD is more frequent in the combined type $(18,19)$. In agreement with these findings, our own results showed that ERD emerged more in the combined type than in the predominantly inattentive type. Based on the model established by Barkley, high emotional instability and high emotional selfregulation characteristics are associated with the primarily hyperactive and impulsive type and the combined type. Low emotional instability and ERDs are associated with the primarily inattentive type. High emotional instability and optimal level ERDs are associated with a primarily hyperactiveimpulsive type and combined type (20). In our study, however, due to the features of the measurement tool we used in the evaluation of ERD it was not possible to examine these sub-concepts of emotional regulation or to investigate their relation with different clinical types of ADHD.

Another factor thought to have a potential effect on ERD in ADHD is the presence of comorbid psychiatric diagnoses. Behavioral problems accompanying ADHD have been reported to be capable of affecting ERD (21). One study examining ERD in individuals with ADHD revealed greater difficulty in subjects exhibiting high aggression. On the other hand, it has also been reported that ERD in ADHD needs to be distinguished from irritability in accompanying psychiatric disorders. In support of this, the results from some studies show that ERD in ADHD ODD irritability need to be considered as separate symptoms (22). Irritability seen in ADHD is episodic in nature, while that in ODD is chronic. Our study investigated whether or not the presence of comorbid ODD in the ADHD group would have an effect on ERD, but no relation was determined. However, this may be due to the low number of cases with comorbid diagnoses of ODD.

There are a number of limitations to our study. Possible effects on ERD of the presence of comorbid diagnoses in ADHD may not have been revealed due to insufficient case numbers. When the age distribution of cases was considered, the potential effect of the age factor on ERD could not be fully evaluated due to the low number of participants in the adolescent age group. Another limitation is that the measurement tool used in the evaluation of ERD does not measure the stages of emotion regulation separately. 
In conclusion, ERD accompanying ADHD leads to greater loss of function in the individual and is associated with persistence of disorder in adulthood. Although ERD is not one of the identifying criteria, it is still an important clinical feature that should be considered separately in the diagnosis and treatment of ADHD.

\section{REFERENCES}

1. Thompson RA. Emotion regulation: a theme in search of definition. Monogr Soc Res Child Dev 1994;59(23):25-52.

2. Shaw P, Stringaris A, Nigg J, et al. Emotion dysregulation in attention deficit hyperactivity disorder. Am J Psychiatry 2014;171(3):276-93.

3. Stringaris A, Goodman R. Mood lability and psychopathology in youth. Psychol Med 2009; 39(8):1237-45.

4. Copeland WE, Brotman MA, Costello EJ. Normative Irritability in Youth: Developmental Findings From the Great Smoky Mountains Study. J Am Acad Child Adolesc Psychiatry 2015;54(8):635-42.

5. Mick E, Biederman J, Pandina G, et al. A preliminary meta-analysis of the child behavior checklist in pediatric bipolar disorder. Biol Psychiatry 2003;53:1021-7.

6. Diler R, Uğuz S, Seydaoğlu G, et al. Mania profile in community sample of prepubertal children in Turkey. Bipolar Disord 2008;10:546-53.

7. Kutlu A, Akyol UA, Ercan ES. Effect of Methylphenidate on Emotional Dysregulation in Children With Attention-Deficit/Hyperactivity Disorder + Oppositional Defiant Disorder/Conduct Disorder. J Clin Psychopharmacol 2017; 37(2):220-5.

8. Kaufman J, Birmaher B, Brent D. Schedule for School-Age Children-Present and Lifetime Version (KSADS-PL): initial reliability and validity data. J Am Acad Child Adolesc Psychiatry 1997; 36(7):980-8.

9. Gökler B, Ünal F, Pehlivantürk B, et al. Okul Çağı Çocukları için Duygulanım Bozuklukları ve Şizofreni Görüşme Çizelgesi-Şimdi ve Yaşamboyu Şekli-Türkçe Uyarlamasının Geçerliliği ve Güvenilirliği. Çocuk ve Gençlik Ruh Sağlığı Dergisi 2004;11(3):109-16.

10. Achenbach TM. Manual for the Child Behavior Checklist/4-18 and 1991 profile. University of Vermont, Department of Psychiatry, Burlington VT, 1991.

11. Faraone SV, Asherson P, Banaschewski T, et al. Attention-deficit/hyperactivity disorder. Nat Rev Dis Primers 2015;1:15020.

12. Anastopoulos AD, Smith TF, Garrett ME, et al. Self-Regulation of Emotion, Functional Impairment, and Comorbidity Among ChildrenWith AD/HD. J Atten Disord 2011;15(7):583-92.

13. Lee CA, Milich R, Lorch EP, et al. Forming first impressions of children: the role of attentiondeficit/hyperactivity disorder symptoms and emotion dysregulation. J Child Psychol Psychiatry 2018;59(5):556-64.

14. Bunford N, Evans SW, Langberg JM. Emotion Dysregulation Is Associated With Social Impairment Among Young Adolescents With ADHD. J Atten Disord 2018; 22(1):66-82.

15. Banaschewski T, Jennen-Steinmetz C, Brandeis D, et al. Neuropsychological correlates of emotional lability in children with ADHD. J Child Psychol Psychiatry 2012;53(11):1139-48.

16. Özyurt G, Pekcanlar AA, Öztürk Y, et al. Dikkat eksikliği ve hiperaktivite bozukluğu olan çocuklarda ve annelerinde duygu düzenlemenin araştırılması. Anadolu Psikiyatri Derg 2016;17:393-402.

17. Barkley RA. Emotional dysregulation is a core component of ADHD. In RA. Barkley (Ed.), Attention-deficit hyperaktivity disorder. A handbook for diagnosis and treatment (4th edn) New York: Guilford Press, 2015.

18. Sobanski E, Banaschewski T, Asherson P, et al. Emotional lability in children and adolescents with attention deficit/hyperactivity disorder (ADHD): clinical correlates and familial prevalence. J Child Psychol Psychiatry 2010;51(8):915-23.

19. Vidal R, Valero S, Nogueira M, et al. Emotional lability: the discriminative value in the diagnosis of attention deficit/hyperactivity disorder in adults. Compr Psychiatry 2014;55(7):1712-9.

20. Faraone SV, Rostain AL, Blader J, et al. Practitioner Review: Emotional dysregulation in attentiondeficit/hyperactivity disorder - implications for clinical recognition and intervention. J Child Psychol Psychiatry 2019;60(2):133-50.

21. Nigg JT, Casey BJ. An integrative theory of attention-deficit/ hyperactivity disorder based on the cognitive and affective neurosciences. Dev Psychopathol 2005;17(3):785-806.

22. Liu L, Chen W, Vitoratou S, et al. Is Emotional Lability Distinct From "Angry/Irritable Mood," "Negative Affect," or Other Subdimensions of Oppositional Defiant Disorder in Children With ADHD? J Atten Disord, 2016. https://doi.org/10.1177/1087054715624228. 